\title{
Individual diversity management and salutogenic functioning
}

\author{
FRANS CILLIERS
}

Department of Industrial and Organisational Psychology, University of South Africa, Pretoria, South Africa

\begin{abstract}
Individual diversity management was framed as how individual managers engage with and experience diversity situations. Salutogenesis was chosen as the psychological model to understand individuals' management of diversity. The aim of the research was to investigate whether and how sense of coherence (SOC) acts as differentiator between ineffective and effective diversity management amongst managers. Based on their quantitatively measured SOC scores, 33 managers in a financial services organization were divided into a (statistically significantly different) low and high functioning subgroup. This was followed by a qualitative interview based on their experienced comprehension, manageability and meaningfulness of diversity experiences. Compared to the low subgroup, the high SOC subgroup reported understanding of the necessity of diversity discussions, managing themselves as representatives of a specific race, gender and age group, and finding diversity experiences meaningful towards identity forming and effective interpersonal relationships. Their SOC was linked to other salutogenic constructs. It was recommended that this organization design its diversity programme based on salutogenesis as theoretical model.
\end{abstract}

\section{Introduction}

Organizations worldwide are increasingly challenged by diversity phenomena such as globalization, democratization and human rights (Cross, 2000; Holvino, 2003; Meyer \& Boninelli, 2007). From a systemic perspective, diversity management refers to how organizations (on the macro level) plan, organise, lead and control incentives and programmes to promote effective task outcomes and harmony amongst employees, how teams (on the meso level) manage themselves towards accepting their internal differences, and how (on the micro level) individual employees manage their boundaries working across differences (Human, 2005; Nohria \& Khurana, 2010). This research focused on the micro level, i.e. how individual managers experience diversity situations intra- and interpersonally. The diversity literature indicates that the effective management of such diversity situations depends on the managers' level of psychological functioning (Booysen, 2005; Pretorius, 2003). No research could be found investigating managers' diversity experiences in this context. For purposes of this study salutogenesis (Strümpfer, 1990) was chosen as psychological model (Peltier, 2001).

\section{Diversity and individual diversity management}

In the above context, diversity is defined as the presence of people with different and subjectively experienced identities based on their unique conscious and unconscious characteristics in one social system (Arredondo, 1996; Coetzee, 2007; Thomas, 1996). Primary diversity dimensions (Reece \& Brandt, 1993) refer to core individual attributes that cannot be influenced or changed (such as age, gender, race, ethnicity, physical appearance or traits, and sexual orientation). These dimensions are crucial in forming the individual's self-image and act as filters through which the world is seen and experienced. Secondary diversity dimensions (Reece \& Brandt, 1993) are changeable (such as physical or mental capability, commun ication style, education, social/relationship/marital/parental status, religious beliefs, career, work experience, and income). These dimensions add complexity to the individual's selfimage. The interaction between the primary and secondary dimensions shapes individuals' values, priorities and perceptions, their interpersonal behaviour as well as the organization's products and services (Holvino, 2003).

Correspondence: Frans Cilliers, Department of Industrial and Organisational Psychology, PO Box 392, UNISA 0003, South Africa. Tel: +27.83 .709 .8776$. Fax: +27.12.429.8368. E-mail: cillifvn@unisa.ac.za 


\section{F. Cilliers}

Individual diversity management describes how individuals engage with and experience diversity situations (Chin, 2010; Nohria \& Khurana, 2010). Ineffective diversity management is characterized by the splitting of the similar and the different, and the holding on to preconceived notions and stereotypes about others, especially about their primary diversity dimensions of race and gender (Human, 2005). Effective diversity management is characterized by an integration of similar and different dimensions, and the understanding, accepting and valuing of differences in the self, and between the self and the other (Wheeler, 1996).

South Africa is one of the most diverse countries in the world (Maier, 2002). Since the first democratic election in 1994 and the abolishment of apartheid, South African organizations have become intensely aware of the differences between employees. Consequently, many diversity programmes were designed and presented focusing on social and cultural backgrounds, religious practices, rites of passage according to ethnic or religious roots, perceptions about politeness, social correctness, generosity and time, languages, dietary laws, dress codes and cultural taboos (Booysen, 2005; Coetzee, 2007; Human, 2005). Furthermore, legislation on employment equity and affirmative action brought a unique kind of competition for economic and emotional survival into the workplace (Cilliers \& Stone, 2005). In some organizations, the intolerances for the differences led to discomfort, disrespect and strong feelings of racial fear, anger, resentment, conflict, competition, hurt, hopelessness and helplessness amongst employees (Cilliers \& May, 2002; Pretorius, 2003). Managing diversity effectively relates to how managers can facilitate harmonious relationships between different people (Cilliers \& Terblanche, 2010), through cognitive understanding and the experience of emotional meaning making (Watts, 2009). In South African diversity issues manifest mostly as race, gender and age differences followed by organization level and thinking paradigm differences (Cilliers \& May, 2002).

\section{Salutogenic functioning}

Antonovsky $(1979,1987)$ conceptualized salutogenesis as (what has since been framed) a positive psychology paradigm or framing concept (Breed et al., 2006). As such, it focuses on the origins of health and wellness, the locating and developing of personal and social resources and adaptive tendencies relating to individuals' disposition, allowing them to select appropriate strategies to deal with confronting stressors and anxieties. Salutogenesis is operationalized as sense of coherence (SOC) (Antonovsky, 1987, 1993) defined as a global orientation that expresses the extent to which one has a pervasive, enduring, though dynamic feeling of coherence. This includes (1) comprehensibility (that the stimuli deriving from the internal and external environment in the course of living are structured, predictable, explicable and making sense), (2) manageability (the belief that resources are available to meet the demands posed by the stimuli and coping with these), and (3) meaningfulness (the belief that demands are worthy of investment and emotional engagement).

\section{Integration}

Salutogenesis and SOC were chosen as a psychological perspective in this study because of its philosophical, descriptive and value resemblance with the literature on management (Peltier, 2001; Sheldon \& King, 2001). The criteria for effective management (Meyer \& Boninelli, 2007; Nohria \& Khurana, 2010) can be linked to the three SOC dimensions. Management intelligence and understanding link with SOC comprehensibility, internal motivation (e.g. locus of control) and the management of individual and interpersonal resources with SOC manageability, and emotional sensitivity and awareness to SOC meaningfulness. South African research on SOC has provided evidence of a relationship with many organisational and relationships between organizational and management constructs and dimensions (Rothmann, 2002; Strümpfer, 1990, 1995; Wissing \& Van Eeden, 2002). However, no study could be found linking SOC to diversity experiences. Positive psychology research on coaching (Linley \& Joseph, 2004) comments on how managers become more tolerant once they start functioning on higher levels of constructs such as happiness and character strengths (Biswas-Diener \& Dean, 2007), emotional intelligence (Wall, 2007), resilience (Maddi \& Khoshaba, 2005) and SOC (Cilliers, 2011).

\section{Research problem and aim}

Generally, managers struggle more with people than task management (Blake \& McCanse, 1995), especially in organizations where practitioners from the natural or number sciences enter management levels (Cilliers, 2011). This study focused on managers in a financial services organization. In their professional training as auditors, the managers have become used to rightand-wrong thinking, to strictly apply rules and regulations, and to apply values related to predictability and governance (Beck \& Cowan, 2006; Cowan \& Todorovic, 2010). These values predict difficulty in coping with diversity, difference and exception (Cilliers \& Coetzee, forthcoming). The research question was formulated as: Does salutogenic functioning operationalized as SOC act as a diversity management differentiator? The 
aim of the research was to investigate whether and how SOC acts as differentiator between ineffective and effective diversity management amongst managers.

\section{Methods \\ Research design and strategy}

The study was set in a South African financial organization interested in how its managers experience diversity. A mixed method, exploratory sequential (Creswell \& Plano Clarke, 2011) and participatory (Brewerton \& Millward, 2004) design was used. Phase 1 was conducted from the positivist paradigm using quantitative measurement (Terre Blanche et al., 2006) of SOC, and phase 2 from the hermeneutic paradigm (Clarke \& Hoggett, 2009) using qualitative interviewing (Camic et al., 2003) on individual diversity management. The strategy involved a single case study (Bassey, 1999) used for its intrinsic (obtaining theoretical and practical understanding) and instrumental (providing feedback to the organization) values (Denzin \& Lincoln, 2005).

\section{Sample}

A convenient and opportunistic sample (Terre Blanche et al., 2006) was used consisting of 33 senior managers responsible for financial project management - 22 men and 11 women, 13 black (including 6 Indian) and 20 white, between 29 and 53 years of age with at least three years tertiary education. The sample was seen as representative of the South African management level work force and its size was seen as sufficient to answer the research question supported by a significant existing body of theoretical knowledge in the field of salutogenesis (Alvesson \& Sköldberg, 2010).

\section{Instruments and analysis}

In phase 1 , the Orientation to Life Questionnaire (OLQ) (29-item) (Antonovsky, 1987) was used to measure SOC (as defined above). Antonovsky (1993) reported alpha coefficients in 29 studies varying between 0.85 and 0.91. Muller and Rothmann (2009) reported an average alpha coefficient of 0.93 and high inter-correlations between the three SOC dimensions in the South African context. Descriptive statistics ranked the sample's total SOC scores from low to high (1-33) and t-tests were calculated to ascertain the significance of differences (Terre Blanche et al., 2006) between the low and high subgroup scores (using SPSS, 2003). (To ensure a blind analysis of the interviews in phase 2 , the above statistical analysis was only done after the interviews were conducted and analysed.)
In phase 2, data collection consisted of a 1-h indepth interview (Clark \& Hoggett, 2009) using the following questions (based on the three SOC dimensions): How do you understand diversity management in this organization; how do you manage diversity situations; how do you make meaning of your diversity experiences in this organization? The 33 interviews were tape recorded and transcribed. The data was content analysed using simple hermeneutics to understand participants' subjective and inter-subjective experiences and double hermeneutics to allow for the critical interpretation of their experiences (Alvesson \& Sköldberg, 2010) from a salutogenic perspective (Antonovsky, 1987). The process of interpretation (Terre Blanche et al., 2006) involved familiarization, immersion and crystallization followed by the categorizing of diversity management experiences into salutogenic comprehensibility, manageability and meaningfulness. Lastly, the data was integrated into a research hypothesis (Schafer, 2003).

\section{Ensuring quality data}

Trustworthiness (Brewerton \& Millward, 2004; Camic et al., 2003; Denzin \& Lincoln, 2005) was ensured throughout the research. The organization authorized the researcher in his role as consultantpsychologist; he assured all participants of confidentiality; they partook voluntarily and with conformed consent; data gathering was contracted at mutually convenient hours in a board room with easy access for all. Thus, ethicality was ensured (Terre Blanche et al., 2006). Credibility was applicable in having two independent psychologists (to whom the theoretical model is well known) to peer-review the results. They declared the research dependable and agreed on its saturation (Denzin \& Lincoln, 2005) which confirmed internal generalizability (Maxwell, 1992). The study evidenced strong and believable validity in its psychological description, which revealed the complexities of salutogenic functioning. Confirmability was attended to in keeping the data analysis in phases 1 and 2 separate to ensure a blind analysis of the interviews. The researcher also reflected on how the results lead to the themes and research hypothesis. Transferability was assured by reflecting on the findings in relation to similar salutogenesis research in the field of management (Biswas-Diener, 2010; Kilburg \& Diedrich, 2007; Stout Rostron, 2009).

\section{Results}

\section{Phase 1}

The descriptive statistics indicated the sample's total SOC scores to be grouped into a low $(\mathrm{N}=11 ; 7 \mathrm{men} / 4$ women; 5 black $/ 6$ white), medium $(\mathrm{N}=8 ; 5 \mathrm{men} / 3$ 
Table I. T-test significance of differences between the low and high SOC subgroups.

\begin{tabular}{lcrrcrc}
\hline Subgroup & $\mathrm{N}$ & $\mathrm{X}$ & $\mathrm{SD}$ & $\mathrm{T}$ & $\mathrm{DF}$ & Probability \\
\hline Low SOC & 11 & 88.45 & 10.72 & -16.63 & 7,2 & 0.00 \\
High SOC & 14 & 132.56 & 15.31 & -16.37 & 8,9 & 0.00 \\
\hline
\end{tabular}

women; 4 black $/ 4$ white), and high $(\mathrm{N}=14 ; 10 \mathrm{men} / 4$ women; 4 black/10 white) subgroup. The t-test results indicated a significant difference between participants with low and high SOC scores (see Table I). (The medium SOC score subgroup did not show significant differences with the other two subgroups - therefore their data was not interpreted.) The quantitative data was interpreted as a valid difference between low and high SOC scores.

\section{Phase 2}

\section{Low SOC and individual diversity management}

- Comprehensibility. Participants avoided the question on comprehension or talked around it as if it did not make sense to them, some externalized the matter, while others gave a critical evaluation of what diversity is, what it should be and what is wrong with diversity management in the organization. They spoke about the differences between them and others in a vague, distant and disconnected manner. They referred to how the organization's diversity endeavours 'do not make sense' and 'is a waste of time' and 'money'. They referred to 'diversity issues in society' as 'causing chaos' and 'disrupting society'. They did not refer to any similarity between people or colleagues.

- Manageability. Participants reported on their difficulty to manage themselves amidst differences of race, gender and level in the organization, up to the point of being out of control, giving up and threatening with flight responses of resigning. It was as if they were overwhelmed by something larger than themselves which led to a sense of being discriminated against by 'people who were so different from me'. Three participants blamed management for not ensuring 'that people are allowed to live out their principles'.

- Meaningfulness. Participants' behaviour evidenced high levels of anxiety with differences, fear, threat, confusion, discomfort and paranoid feelings about being watched by the other. Their defences manifested as detachment ('these issues are not important'; 'diversity is too airy-fairy to take seriously'), avoidance ('I just look the other way'; 'I wish I could live where there are no differences'), denial and generalization ('I believe that we are all the same'), projections (black/white people 'have to act responsibly' and 'know their place') and idealization
('I miss the times when life was simple'). Some participants spoke in an emotionally detached manner about their experiences and some exhibited hopelessness. Some participants even expressed their discomfort in sharing their experiences in the interview for fear of 'what the consequences could be'.

\section{High SOC and individual diversity management}

- Comprehensibility. Participants illustrated their understanding of the manifestation of diversity matters, the necessity to attend to these in organizational context and the detriment to interpersonal relations if diversity is denied or not managed effectively. Effectiveness was framed as awareness of the self ('even under difficult circumstances'), the effect of the self on other people ('how I am seen by others'; 'what I represent for them') and an openness to talk about these experiences. They used 'welanguage' to describe diversity as an organizational manifestation which all employees are involved in.

- Manageability. Participants expressed their willingness to engage with diversity matters. For some 'this is still difficult' to work with 'the conflict between race groups', 'without a clear howto-do-it file'. Participants tend to cope in a sophisticated manner using intellectualization ('if only we can continue to find common ground in what we do'; 'allow one another the space we claim for ourselves'). The discussions always ended with hope ('we have moved towards more openness'; 'acceptance') and self-authorization ('I am committed to keep trying to listen to what others are saying and to support everyone').

- Meaningfulness. Participants spoke about their own and personal experiences, and anxiety about 'diversity as something daunting' was contained in their optimism and managing of their positive feelings around 'wanting to work effectively together'. They expressed their efforts to find meaning in the paradox of finding 'diversity discussions daunting' as well as 'when I open myself up to myself I may let the other-ness in'. Their attachment to growth of the self, others and the organization was underlying their resilience to keep trying to make sense out of differences. For two participants a form of objectification helped to cope with difference ('I know I find difference threatening and I suppose then others find me threatening'; 'It is really about what you represent for the other person'). One participant referred to 'turning problems into possibilities' as a way of using emotional energy to stay positive.

The research hypothesis was formulated as follows: Low SOC manifested as detachment from and splitting of the primary diversity dimensions, and high SOC as intellectual and emotional attachment 
to and integration of diversity experiences. Compared to the low levels, high levels of SOC facilitate an understanding of the necessity of processing diversity experiences, sharing these with the other, managing oneself and others as representatives of a specific race, gender or age group, and finding diversity experiences meaningful towards identity forming and effective interpersonal relationships.

\section{Discussion}

The aim of the research was to investigate whether and how SOC acts as differentiator between ineffective and effective diversity management amongst managers. The results indicated that managers measuring high on SOC manage diversity in a different, more integrated and attached manner than managers measuring low on SOC.

Although only SOC was measured quantitatively in this research, the data gave evidence of many other salutogenic (Strümpfer, 1990, 1995, 2005) and positive psychology constructs (Snyder \& Lopez, 2009) present in effective diversity management. Next, the manifestation of these constructs are interpreted based on the strong theoretical and empirical interconnectedness between SOC and emotional intelligence, managing positive emotions, work engagement, psychological wellness, psychological and character strengths, people and synergistic values, authorization and management style (see Biswas-Diener, 2010; Breed et al., 2006; Cilliers \& Coetzee, 2003; Jackson, 2004; Kauffman, 2006; Linley \& Joseph, 2004; Naudé \& Rothmann, 2006; Peterson, 2000; Peterson \& Seligman, 2004; Pretorius, 2007; Rothmann, 2002; Ryan \& Deci, 2000; Sheldon et al., 2011; Sheldon \& King, 2001; Storm, 2001; Strümpfer et al., 2010; Van Der Colff \& Rothmann, 2009; Van Zyl et al., 2010; Wissing \& Van Eeden, 2002).

- Emotional intelligence (Bar-On, 2010; Cherniss, 2010; Goleman, 1995; Goleman et al., 2008; Jonker, 2009; Wall, 2007) manifested as a willingness to explore one's own and others' needs and feelings and to make meaningful connections as human beings. The lack of emotional intelligence manifested in one manager as alexithymia (the condition of having no access to feelings (Goleman, 1995)).

- The managers' ability towards managing positive emotions (Frederickson, 2001), emotional risk taking and coping with difficult emotions (Kashdan, 2009) were evident in how they described their excitement, joy and happiness as well as how guilt and shame (as negative emotions) were acknowledged.

- Work engagement and its relatedness with SOC and coping (Van der Colff \& Rothmann, 2009) manifested in managers' vigorous energy and perseverance to attach to difficult experiences as well as their dedication to use enthusiasm and inspiration to form meaningful relationships for the sake of the self and the organization.

- Psychological wellness (Peterson, 2000; Ryan \& Deci, 2000) manifested in terms of autonomy and optimism. Ineffective diversity management suggested a denial of the importance of feelings around diversity and the avoidance of own and others' emotional experiences. Effective diversity management reflected a resilience to stay with difficult experiences and feelings for longer periods of time. According to Maddi and Khoshaba (2005) this resilience is based on hardiness, defined as patterns of attitudes to cope with stressful situations and to turn distress into eustress, followed by the courage and motivation to use the hard skills of coping, social support and self-care as opposed to denial and avoidance. It was interpreted that these managers could change their attitudes towards higher levels of commitment, control and challenge and that their coping was enhanced towards higher levels of mental perceptiveness and understanding of decisive management action.

- Psychological and character strengths (Snyder \& Lopez, 2009) manifested in openness to learning about and investigating their own emotional experiences, illustrating mindfulness and curiosity (Kashdan, 2009) based on personal (intrapersonal) strengths (Biswas-Diener, 2010).

- People and synergistic values (as described in the spiral dynamics theory (Beck \& Cowan, 2006; Cowan \& Todorovic, 2010)) manifested in how differences were respected and (not seen as opposites, but) seen as synergistically connected ('both sides of the same coin'). On the other hand ineffective diversity management manifested as task and governance (blue) values with the preference for separation, power, control, rules, structure, procedure, routines, order, tradition and punishment.

- Self-authorization (versus hiding behind external authority such as religion and organizational power) manifested in how managers could speak with personal conviction, aware of their impact on others, and willing to take responsibility for their views and feelings (Cilliers \& May, 2010).

- The management style (Goleman et al., 2008; Rooke \& Torbert, 2005) associated with effective diversity management was transformational (compared to transactional). Linking this interpretation with Rooke and Torbert's (2005) work, ineffective diversity management gets expressed in the expert style, by managing through logic, expertise and rational efficiency. Effective diversity management was expressed in the achiever style, characterized 
by their awareness of achievement of goals and the management of expectations and behaviours. According to the conceptualization by Goleman et al. (2008) ineffective diversity management was linked to the coercive (dominant), authoritative (directive, goal driven) and pacesetting (setting high standards for performance, driving numbers, a tendency to micro manage, non-empathetic) styles. Effective diversity management manifested in the affiliative (showing an increased awareness of people, bonding, alliances, creation of harmony) and the democratic (influencing, appreciation for others' contribution and commitment) styles.

This research could be seen as a first step towards understanding the relationship between diversity management and salutogenic functioning. The conclusion was formulated that salutogenic functioning operationalized as SOC plays a determining role in diversity management amongst these managers. High levels of salutogenesis seem to facilitate an orientation to diversity characterized by understanding what it entails, it provides self-managerial competence to deal with the sometimes difficult diversity matters, a sense of emotional meaning making and transformational management styles.

The limitations of this research referred to the design and method. From a qualitative design perspective the sample was small, although the data was evaluated as rich enough to support the research hypothesis. As in all qualitative research the subjectivity of the researcher played a role. To counter his subjectivity, the researcher tried to report as fully as possible all the methods used.

In feeding back the results to the organization, the researcher recommended that a salutogenic diversity programme be designed, presented and evaluated for management with the expectation that the organization's diversity management will be enhanced and optimized. This study also recommends that more quantitative and qualitative research is done towards the understanding of the depth of the role of salutogenesis in diversity experiences.

Declaration of interest: The author report no conflicts of interest. The author alone is responsible for the content and writing of the paper.

\section{References}

Alvesson, M. \& Sköldberg, K. (2010). Reflexive Methodology. New Vistas for Qualitative Research. Los Angeles, CA: Sage.

Antonovsky, A. (1979). Health, Stress and Coping. San Francisco, CA: Jossey-Bass.

Antonovsky, A. (1987). Unraveling the Mystery of Health: How People Manage Stress and Stay Well. San Francisco, CA: JosseyBass.

Antonovsky, A. (1993). The structure and properties of the Sense of Coherence scale. Social Science and Medicine, 36, 725-733.
Arredondo, P. (1996). Successful Diversity Management Initiatives: A Blueprint for Planning and Implementation. Thousand Oaks, CA: Sage.

Bar-On, R. (2010). Emotional intelligence: An integral part of positive psychology. South African fournal of Psychology, 40, 54-62.

Bassey, M. (1999). Case Study Research in Educational Settings. Buckingham: Open University Press.

Beck, D.E. \& Cowan, C.C. (2006). Spiral Dynamics: Mastering Values, Leadership and Change. Oxford: Blackwell.

Biswas-Diener, R. (2010). Practicing Positive Psychology Coaching: Assessment and Strategies for Success. Hoboken, NJ: Wiley.

Biswas-Diener, R. \& Dean, B. (2007). Positive Psychology Coaching. Hoboken, NJ: Wiley.

Blake, R.R. \& McCanse, A.A. (1995). Leadership Dilemmas - Grid Solutions. Houston, TX: Griff.

Booysen, L. (2005). Social identity changes in South Africa: Challenges facing leadership. Inaugural lecture, Graduate School of Business Leadership, University of South Africa, 23 June.

Breed, M., Cilliers, F. \& Visser, D. (2006). The factor structure of six salutogenic constructs. South African fournal of Industrial Psychology, 32, 73-85.

Brewerton, P. \& Millward, L. (2004). Organisational Research Methods. A Guide for Students and Researchers. London: Sage.

Camic, P.M., Rhodes, J.E. \& Yardley, L. (2003). Qualitative Research in Psychology. Washington, DC: American Psychological Association.

Cherniss, C. (2010). Emotional intelligence: Towards clarification of a concept. Industrial and Organisational Psychology, 3, 110-126.

Chin, J.L. (2010). Introduction to the special issue on diversity and leadership. American Psychologist, 65, 150-156.

Cilliers, F. (2011). Positive psychology leadership coaching experiences in a financial organisation. South African fournal of Industrial Psychology, 37, 1-14.

Cilliers, F. \& Coetzee, S.C. (2003). The theoretical-empirical fit between three psychological wellness constructs: Sense of coherence, learned resourcefulness and self-actualisation. South African fournal of Labour Relations, 27, 4-24.

Cilliers, F. \& Coetzee, M. (forthcoming). A psychological profile of leaders in a financial organisation. Submitted for publication.

Cilliers, F. \& May, M. (2002). South African diversity dynamics. Reporting on the 2000 Robben Island Diversity Experience. A Group Relations event. South African fournal of Labour Relations, 26, 42-68.

Cilliers, F. \& May, M. (2010). The popularisation of positive psychology as a defence against behavioural complexity in research and organisations. South African fournal of Industrial Psychology, 36, doi:10.4102/sajip.v36i2.917

Cilliers, F. \& Stone, K. (2005). Employment equity practices in three South African information technology organisations: A systems psychodynamic perspective. South African fournal of Industrial Psychology, 31, 49-57.

Cilliers, F. \& Terblanche, L. (2010). The systems psychodynamic leadership coaching experiences of nursing managers. Health SA Gesondheid, 15, doi:10.4102/hsag.v15i1.457

Clarke, S. \& Hoggett, P. (2009). Research Beneath the Surface. Psycho-Social Research Methods in Practice. London: Karnac.

Coetzee, O. (2007). Exploring interpersonal and inter-group diversity dynamics in South African organisations by means of a theoretical model. Doctoral thesis, University of South Africa, Pretoria.

Cowan, C. \& Todorovic, N. (2010). The never ending quest: Clare W. Graves explores human nature. www.spiraldynamics.org

Creswell, J.W. \& Plano Clark, V.L. (2011). Designing and Conducting Mixed Methods Research. Los Angeles, CA: Sage.

Cross, E.Y. (2000). Managing Diversity - The Courage to Lead. London: Quorum.

Denzin, N.K. \& Lincoln, Y.S. (2005). The Sage Handbook of Qualitative Research. London: Sage. 
Fredrickson, B.L. (2001). The role of positive emotions in positive psychology. American Psychologist, 56, 218-226.

Goleman, D. (1995). Emotional Intelligence. New York: Bantam.

Goleman, D., Boyatzis, R. \& McKee, A. (2008). The New Leaders. Transforming the Art of Leadership into the Science of Results. London: Sphere.

Holvino, E. (2003). Theories of differences: Changing paradigms for organisations. In D.L. Plummer (Ed.), Handbook of Diversity Management: Beyond Awareness to Competency-Based Learning (pp. 111-132). Lanham, MD: University Press of America.

Human, L. (2005). Diversity Management for Business Success. Pretoria: Van Schaik.

Jackson, L.T.B. (2004). Burnout and Engagement of Teachers in the North West Province. Doctoral thesis, North-West University, Potchefstroom.

Jonker, C.S. (2009). The effect of an emotional intelligence development programme on accountants. South African fournal of Human Resources Management, 7, doi:10.4102/sajhrm.v7i1.183.

Kashdan, T. (2009). Curious? Discover the Missing Ingredient to a Fulfilling Life. New York: William Morrow.

Kauffman, C. (2006). Positive psychology. The science at the heart of coaching. In D. Stober \& A.M. Grant (Eds). Evidence Based Coaching Handbook. New York: Wiley.

Kilburg, R. \& Diedrich, R. (2007). The Wisdom of Coaching: Essential Papers in Consulting Psychology for a World of Change. Washington, DC: American Psychological Association.

Linley, P.A. \& Joseph, S. (2004). Positive Psychology in Practice. Hoboken, NJ: Wiley.

Maddi, S.R. \& Khoshaba, D.M. (2005). Resilience at Work. How to Succeed no Matter What Life Throws at You. New York: AMACOM.

Maier, C. (2002). Leading Diversity - A Conceptual Framework. Bamberg: Difo-Druck.

Maxwell, J.A. (1992). Understanding and validity in qualitative research. Harvard Educational Review, 62, 279-299.

Meyer, T.N.A. \& Boninelli, I. (2007). Conversations in Leadership. South African Perspectives. Randburg, South Africa: Knowres.

Muller,Y. \& Rothmann, S. (2009). Sense of coherence and employees' perception of helping and restraining factors in an organisation. South African Fournal of Industrial Psychology, 35, 89-98.

Naudé, J.L.P. \& Rothmann, S. (2006). Work-related well-being of emergency workers in South Africa. South African Fournal of Psychology, 36, 63-81.

Nohria, N. \& Khurana, R. (2010). Handbook of Leadership Theory and Practice. Boston, MA: Harvard Business Press.

Peltier, B. (2001). The Psychology of Executive Coaching. Theory and Application. New York: Brunner-Routledge.

Peterson, C. (2000). The future of optimism. American Psychologist, 55, 44-55.

Peterson, C. \& Seligman, M.E.P. (2004). Character Strengths and Virtues: A Handbook and Classification. New York: American Psychological Association.

Pretorius, L. (2007). Resilience, self-efficacy and burnout of employees in a chemical organisation. Master's dissertation, North-West University, Potchefstroom.

Pretorius, M. (2003). An exploration of South African diversity dynamics. Master's dissertation, University of South Africa, Pretoria.

Reece, B.L. \& Brandt, R. (1993). Effective Human Relations. Boston, MA: Houghton Mifflin.
Rooke,D. \& Torbert, W.R. (2005). Seven transformations of leadership. Harvard Business Review, April, 1-11.

Rothmann, S. (2002). Burnout and engagement: A fortigenic perspective. Inaugural lecture, Potchefstroom University, South Africa.

Ryan, R.M. \& Deci, E.L. (2000). Self-determination theory and the facilitation of intrinsic motivation, social development and well-being. American Psychologist, 55, 68-78.

Schafer, R. (2003). Insight and Interpretation. The Essential Tools of Psychoanalysis. London: Karnac.

Sheldon, K.M., Kashdan, T.B. \& Steger, M.F. (2011). Designing the Future of Positive Psychology. Oxford: Oxford University Press.

Sheldon, K.M. \& King, L. (2001). Why positive psychology is necessary. American Psychologist, 56, 216-217.

Snyder, C.R. \& Lopez, S.J. (2009). Oxford Handbook of Positive Psychology. New York: Oxford University Press.

SPSS (2003). SPSS 12.0 for Windows. Chicago: SPSS.

Storm, K. (2002). Burnout and work engagement of teachers in the South African Police Services. Doctoral thesis, Potchefstroom University, South Africa.

Stout Rostron, S. (2009). Business Coaching. Wisdom and Practice. Unlocking the Secrets of Business Coaching. Randburg: Knowledge Resources.

Strümpfer, D.J.W. (1990). Salutogenesis: A new paradigm. South African fournal of Psychology, 20, 265-276.

Strümpfer, D.J.W. (1995). The origins of health and strength: From 'salutogenesis' to 'fortigenesis'. South African fournal of Psychology, 25, 81-89.

Strümpfer, D.J.W. (2005). Standing on the shoulders of giants: Notes on early positive psychology (Psychofortology). South African fournal of Psychology, 35, 21-45.

Strümpfer, D.J.W., Eiselen, R.J., Meiring, D. \& Phalatse, J.S. (2010). Validating measures of psychological well-being by contrasting samples employees in hazardous and less hazardous work. Fournal of Psychology in Africa, 20, 23-32.

Terre Blanche, M., Durrheim, K. \& Painter, D. (2006). Research in Practice. Applied Methods for the Social Sciences. Cape Town, South Africa: UCT Press.

Thomas, R.R. (1996). Redefining Diversity. New York: American Management Association.

Van Der Colff, J.J. \& Rothmann, S. (2009). Occupational stress, sense of coherence, coping, burnout and work engagement of registered nurses in South Africa. South African Fournal for Industrial Psychology, 35, doi: 10.4102/sajip.v35i1.423.

Van Zyl, L.E., Deacon, E. \& Rothmann, S. (2010). Towards happiness: Experiences of work-role fit, meaningfulness and engagement of industrial / organisational psychologists in South Africa. South African Fournal of Industrial Psychology, 36, doi:10.4102/sajip.v36i1.890.

Wall, B. (2007). Coaching for Emotional Intelligence. New York: AMACOM.

Watts, L. (2009). Managing self in role: Using multiple methodologies to explore self construction and self governance. In $S$. Clarke \& P. Hoggett. Researching Beneath the Surface. PsychoSocial Research Methods in Practice. London: Karnac.

Wheeler, M.L. (1996). Corporate Practices in Diversity Measurement. Report no 1164-96-RR. New York: Conference Board.

Wissing, M.P. \& Van Eeden, E. (2002). Empirical clarification of the nature of psychological well-being. South African fournal of Psychology, 32, 32-44. 
Copyright of International Review of Psychiatry is the property of Routledge and its content may not be copied or emailed to multiple sites or posted to a listserv without the copyright holder's express written permission. However, users may print, download, or email articles for individual use. 